\title{
Polysemy and Homonymy Seen in Their Stylistic Use
}

\author{
Sonila Daiu, PhD. Cand. \\ "Aleksander Xhuvani" University \\ sonilatanku@yahoo.com
}

\begin{abstract}
This article is concerned with stylistic phenomenon of polysemy and homonymy. Treated together they represent not only a complex linguistic phenomenon but also a stylistic one, which deserves proper treatment. In this article we mainly deal with the main sources of polysemy and homonymy in both English and Albanian Language in order to have a better understanding within the stylistic use. Using the comparative approach, we have tried to group the main sources of polysemy and homonymy, illustrated with examples.
\end{abstract}

Keywords : polysemy, homonymy, stylistic, lexical - grammatical ,phonetic ambiguity, grammatical ambiguity, lexical ambiguity

\section{Introduction}

The study of semantic issues, especially polysemy and homonymy, is seen in a continuing conflict between theories and arguments of different researchers, who always pose themselves in two directions. On the one hand, are those researchers who concentrate their studies in meaning only within the language, and the relation the meaning has with other linguistic elements. On the other hand, are the arguments that meaning must be studied in a non-linguistic macrostructure, where pragmatic elements play a very important role.

For example, stylistic in itself is not interested in meaning, as it is defined in some linguistic theories or shown in dictionaries. Discourse is related to the actual meaning, that which is produced from the discourse text, with the contextual meaning, with additional meaning that is obtained from the whole structural organizational of meaning, and in the end with special meanings of a speaker ${ }^{1}$. Therefore, we must admit that, except linguistic semantic polysemy and homonymy, there exit a stylistic polysemy and homonymy which is obtained from stylistic organization.

Polysemy and homonymy may rarely cause problems in communication, because the words are used in contexts, which give a lot of data to select the right meaning. Anyhow, most of the time they are used to cause ambiguity as play of words from different authors.

Ambiguity itself represents a kind of hesitation from the listener or the speaker on the selection of the two or more possible meanings that can come from the context. Ambiguity is related to the multiple meaning and give results only when the context is unclear or inadequate to make the right selection.

All words, except some technical or scientific terms, specific nouns and a small number of general nouns which refer to unique objects, mark not an individual unit, but a group of objects or events related with a common element ${ }^{2}$. Always a kind of generalization must be noted as an inevitable way of elements of ambiguity and uncertainty.

Furthermore, words that we use while we talk are not completely homogeneous from meaning: they carry a variety of aspects and patterns depending on the context and situation, and on the speakers' personality. This changes while speaking are the cause of ambiguity 'birth' and in extreme situations of disambiguation.

The nature of outside world can became a source of ambiguity. In our everyday life and environment around us, occur phenomena which melt together and are undifferentiated and we need to divide them in more differentiated units.

\footnotetext{
1 Lloshi, Xh. (2001), Stilistika E gjuhës Shqipe dhe Pragmatika, SHBLU, Tiranë, pg.. 130

2 Jackson, H. And Amvela, Z.E. ( 2007), Words, Meanings and Vocabulary, An Introduction to Modern Lexicology, 2nd Edition, Athenaeum, London, pg. 62
} 
This lack of division, is more 'highlighted' when we deal with abstract phenomena, which themselves do not have a real existence except the words which mark them.

Another variable factor based on person's knowledge and interest, is not knowing the referent. Since, the vocabulary of a language is an open system, which means it can always have new 'flows', and moreover what it is to be mention is the fact that no one is specialized in all fields, and none can pretend to know all the words of a language. This is one of the causes not only of ambiguity but also of the interruption in a ongoing communication.

According to Wellman, "ambiguity is a linguistic condition which may appear in different ways"1. This means, that ambiguity may appear in different linguistic levels as that of phonetic, morphologic, syntax, semantic and pragmatic. All of these fall in three main categories: phonetic, syntax and linguistic ambiguity.

\section{TYPES OF AMBIGUITY}

\section{A. PHONETIC AMBIGUITY}

Phonetic ambiguity was born in spoken language, due to the phonetic structure of the sentence, for example in English language the word near once have had the meaning kidney, but this word was not used anymore with this meaning because a near - a kidney most of the time was confused with the word an ear.

In Albanian also, the accent as an essential element of how a word sounds, performs a variety of functions; among others, marks the divided border between words².

Phonetic ambiguity it is not only related to prose features. Another source are the homophones or partial homophones, which are used for stylistic reasons. Here we can mention some examples of William Shakespeare, who used the word power in both shape and meaning, to play and create purposeful ambiguity.

King Claudius

But now my cousin Hamlet, and my son (1),

Hamlet

[Aside] A little more than kin (2), and less than kind (2)

King Claudius

How is it that clouds still hang on you?

Hamlet

Not, so my lord; I am too much i' the sun (1)

(Hamlet, Act I, Scene II ${ }^{3}$ )

The phonetic ambiguity is created from the homophone 'son' - "i biri" and 'sun' - "dielli" and in the second case from the similarity of forms and meaning kin- " $i$ afërt" nga lidhje farafisnore", and kind - "i dashur" and "i të njëjtit lloj apo soj". All the word-game lies in the fact that Hamlet says to his uncle that we are very close relatives, but not of the same kind (kin) and (kind). On the other hand, with homophone 'sun' and 'son' the possible meanings that come up within the same context are: firstly, it suggests his relative relation, who has replaced his father; secondly, in lighting of presence and king's wellbehaviour; thirdly the sun is the kingdom emblem.

Another writer who uses the words-game skilfully as Shakespeare did is Luis Carol, in his well-known work "Alice's Adventures in Wonderland". The writer describes his work as a kind of play, in the way all Alice's adventures will be in this

\footnotetext{
1 Wellman, S. (1962),Semantics : An Introduction to science of meaning, Barnes \&Nobles, pg. 156

2 Memushaj, R.(2006), Hyrje në Gjuhësi, TOENA, pg. 115

${ }^{3}$ Shakespeare , W. (1599), Hamlet, http://www.feedbooks.com
} 
world. Character's names, places' names, subjects' names and the failure on using the linguistic rules, is in compliance with this world totally different to the real one.

We bring the example of the phonetic ambiguity:

"And how many hours a day did you do lessons? said Alice, in a hurry to change the subject.

"Ten hours the first day," said the Mock Turtle: "nine the next and so".

"That's the reason they're called lessons," the Gryphon remarked: " because they lessen from day to day".

(Chapter IX. The Mock Turtle's Story, fq.45)

Homophones lesson - "mësim" and "lessen" - "zvogëlohen" produce the same context, with two different meanings, where the explanation is given why they are called "mësime" and why they "zvogëlohen" every day.

"You promised to tell me your history, you know," said Alice, "and why it is you hate - C and D," she added in a whisper, half afraid that it would be offended again.

"Mine is a long and a sad tale!" said the Mouse, turning to Alice, and sighing.

"It is a long tail, certainly," said Alice, looking down with wonder at the Mouse's tail; "but why do you call it sad?" And she kept on puzzling about it while the mouse was speaking, so that her idea of the tale was something like that....

(Chapter III. A Caucus - Race and A Long Tale)

The misunderstanding that happens between Alice and the Mouse comes as the result of the use of two homophones 'tale' - "përrallë" and 'tail' -" bisht". When the mouse says my story is " rrëfenjë" long and sad Alice misunderstands, looking at his "bishti" and wondering why was sad, because ...long , of course it was, this was clearly seen.

\section{B. GRAMMATICAL AMBIGUITY}

Another big group is the ambiguity created by the effect of grammatical elements, where we distinguish ambiguity of grammatical forms or that of sentence structure. Some prefixes and suffixes have more than one meaning, what creates not only a homonymic relation, but also the 'birth' of ambiguity, otherwise known like morphologic homonymy, in which the group includes cases where homonymic prefix in1 - "brendësi, përfshirje" and in2 - "parashtese mohore" are two group of words with opposite meaning. In the first meaning, income - "të ardhura", inland - "në brendësi., on the other case the second meaning is formed with words like this : incomplete-"i paplotë", invariable - "i panndryshueshëm", inexperienced - "papërvojë". But we have some other words where in- does not have a negative meaning, in contrary it reinforce more the meaning of the word. Also it exist the suffix - less - with a negative, childless - " pa fëmijë", hopeless - "i pashpresë" and positive meaning as well as in words : priceless - "i paçmueshëm".

Oscar Wild through distorting the rules of word formation in English, presents the school subjects like follows :

"Reeling and Writhing, of course, to begin with," the Mock Turtle replied; " and then the different branches of Arithmetic - Ambition, Distraction, Uglification, and Derision."

( Chapter IX. The Mock Turtle's Story, pg.44)

In the subject of reading from the word reading is created a new word almost similar to it reeling - "përdredhje". As it is an old published book, based on word etymology this might have been used with an old meaning "flet pa pushim". In writing from the word writing we have the word writhing - "përdredhje". In Maths the addition word is done ambition - "qëllim", subtraction has become distraction - "zbavitje", uglification - "shëmtim" into multiplication - "shumëzim" and derision -" përqeshje" and devision - "pjestim".

\footnotetext{
${ }^{1}$ Caroll, L "Alice's Adventure in Wonderland", http//www.gutenberg.org/files/11/11-pdf.pdf
} 
In English, structural ambiguity is more highlighted because of the morphologic characteristics of the language, lexical units often change their lexical-grammatical category, especially the noun and verb. Also the past tense forms correspond to the participles, explored forms must have different functions within a sentence. This "ambivalence" of lexical - grammatical category in English, and not so common in Albanian language, leads to creation of ambiguity.

"Now , I give you fair warning," shouted the Queen, stamping on the ground as she spoke; "either you or your head must be off , and that is about half no time!Take your choice!"

(Chapter IX. The Mock Turtle's Story, pg. 44)

Syntax ambiguity is fully used in humorous parts, but must be found also in different artistic writings or different authors. Continuing with the examples illustration, we can identify the stylistic use.

Guildenstern

What should we say, my lord?

Hamlet

Why, anything, but the purpose. You were sent for;

( Hamlet,Act II, Scene II)

Hamlet's answer related to what Guildenstern asks him, must be interpreted in two ways : he must say everything except the purpose why he was sent, or he must say everything, but only regarding the scope that he was sent.

\section{LEXICAL AMBIGUITY}

Meanwhile, the most important group of ambiguity is the group which is created as a result of lexical factors. In an infinite number of occasions, we have different meanings related to the same word. This happens because the meaning of the word does not show only its relation with an aspect of the real world. Indeed, it might be taken as a result of semantic features derived from affiliation of speech in one or more lexical systems. ${ }^{1}$

This "polyvalence" of words must be displayed in two different forms, where the same word must have two or more different meanings; or two or more different words must have the same phonetic form, the case of homonymy.

Polysemy as well as homonymy broke one of the main rules of language, where the sign language is a unity of the signified and signifier that the speakers have in their brains ${ }^{2}$. The relation between them is that it can't be a signified without a signifier and vice-versa,

the same as a sheet that if ripped, both sides ripes simultaneously. In the case of homonymy we have one responsible signifier for some signifiers and on the other hand in polysemy we have one signified expressed by some signifiers.

Polysemy as well as homonymy, are a rich source of expressions we provide in speech. Polysemy includes in itself a lexical paradigm that within the sentence is obtained one of the meanings. But, some authors are aware of breaking this rule and in the same context come out two or more lexical paradigm. On the other hand homonymy is a false polysemy, as we have the same form, but different meanings, that not only are different in meaning but also different lexemes.

Even though that polysemy is widespread in both English and Albanian language, related to homonymy, in everyday communication is almost invisible. In English language this is a frequent occurrence and this the reason why the use of homonyms is so common in English literature. Focusing in Albanian language homonymy has not been seen as a tool to express different ideas in a speech, except the case of humoristic magazines, in comedies etc.

Examples of polysemy and homonymy are common in the authors mentioned above. Here are some of them:

\footnotetext{
${ }^{1}$ Memushaj, R.( 2006), Hyrje në Gjuhësi, TOENA, pg. 167

2 Rrokaj, Sh. ( 2005), Hyrje në Gjuhësine e Përgjithshme, Shtëpia e Librit Universitar, Tiranë, pg. 34
} 
I. The play of words based in polysemy :

Now, sir, young Fortinbras,

Of unimproved mettle hot and full,

(Hamlet, Act I, Scene I, pg.10)

Inside these rows we have two polysemantic words that make us understand two different things. When he talks about Fotinbras, his name has the meaning - strong in arms - " $\mathrm{i}$ forte në krahë ose armë", the description must be interpreted in two ways : he has a unimproved, temper and spirit, the words are use in their relevant meaning.. mettle - "shpirt, temperament kurajoz" and unimproved - "i,e padisplinuar". But another meaning must be that of the type of the material metal that is another explanation for the word mettle, which is "i paprovuar" - undisciplined.

\section{Words-play based in homonymy}

Mother, good night. Indeed this counsellor

Is now most still, most secret and most grave,

Who was in life a foolish prating knave.

(Hamlet, Act III, Scene IV, pg. 126)

Through the homonymy grave1 - "a varr" and grave2 - "njeri i rëndë, serioz". Shakespeare reaches to adjust both meaning in the same context in the best way possible. After Polonius dead both lexical units with their meanings adjust to context.

Polysemy and homonymy may be seen in artistic and figurative forms of the word which is a way used in Albanian literature and humour programmes. The word play is created in an artificial way for quirks like qe si qe, u bë si ka etc... As a result , artistic humour forms are present in Albanian spectacle "Portokalli" as below :

\section{F2: Gërthisni, mer gërthisni}

Të gjithë: E di Rama, E di Ra ma!

F 5: Po, po, ky e di.E di mire ky.

(Portokalli : Skaleta 9.13, 2010-2011)

Zëri: ....Një ogur(prodigy) i zi ra nga qielli ( a huge stone falls)

Jo gur( stone) idiot! O gur ! ( another stone falls)

Not only homonymy but also polyemy are used to build the unexpected, abrupt solution, needed for the humour. Here is an example of popular creativity:

I thashë njërit:

Kur erdhe?

Neser dy ditë.

Po nga je ti ? 


\author{
Nga shtëpia ime. \\ Ku e ke shtëpinë ? \\ Në mes të oborrit dhe me derë nga lesa. \\ Opo, qënke $i$ trashë ti! \\ Ohu, të shikosh vëllanë tim ti : ta cash, bëhen tre sa unë!
}

It is clearly seen that the epithet or the adjective i trashë ( nga mendja - silly) here it is used in a figurative meaning, as a polysemy used from the prior meaning i bëshëm, i shëndoshë (fat in your body).

\title{
Conclusion
}

In the end we must say that polysemy and homonymy remain lexical issues closely related with every aspect of the use of vocabulary within a language. In an intentional manner or not, they are widely used not only as linguistic features but as stylistic features, too. Difficulties that come while they are used, are the same both in English and Albanian language. Anyway, they take a special significance when talking about teaching or learning a foreign language. Analysing in details the origin and the way they 'meet' together in both languages, gives us some valuable insights in terms of this - so much debated distinction.

\section{References}

Caroll, L “Alice's Adventure in Wonderland”, http//www.gutenberg.org/files/11/11-pdf.pdf

Jackson, H. And Amvela, Z.E. ( 2007), Words, Meanings and Vocabulary, An Introduction to Modern Lexicology, $2^{\text {nd }}$ Edition, Athenaeum, London, pg. 62

Lloshi, Xh. (2001), Stilistika E gjuhës Shqipe dhe Pragmatika, SHBLU, Tiranë, pg.. 130

Memushaj, R.(2006), Hyrje në Gjuhësi, TOENA, pg. 115

Memushaj, R.( 2006), Hyrje në Gjuhësi, TOENA, pg. 167

Rrokaj, Sh. ( 2005), Hyrje në Gjuhësine e Përgjithshme, Shtëpia e Librit Universitar, Tiranë, pg. 34

Shakespeare , W. (1599), Hamlet, http://www.feedbooks.com

Welman,S. (1962),Semantics : An Introduction to science of meaning, Barnes \&Nobles, pg. 156 